\title{
Bauxite Residue Safety Disposal and Possibilities to Further Utilization. \\ Part 1. Acid Soils Remediation
}

\author{
Gheorghe Dobra, Laurentiu Filipescu, \\ Nicolae Anghelovici, Vicol Alistarh, \\ Sorin Iliev and Lucian Cotet* \\ VIMETCO ALUM SA \\ 82 Isaccei Str., Tulcea, 820228, Romania
}

Received 27.02.2017, received in revised form 10.03.2017, accepted 23.03.2017

\begin{abstract}
This paper is presenting the investigations concerning a new approach in acid soil remediation by deep reshaping the land surface layer, in order to change its agrochemical composition and properties. Three property control adjuvant were used for this purpose: the bauxite residue for $\mathrm{pH}$ control, the organic compost as source of organic carbon and better control of the soil properties, and the NPK mineral fertilizers as source of main macronutrients. Doses of 15, 30 and 75 t bauxite residue/ha associated with $40 \mathrm{t} / \mathrm{ha}$ organic compost and $120 \mathrm{Kg} \mathrm{N} / \mathrm{ha}+60 \mathrm{Kg} \mathrm{P}_{2} \mathrm{O}_{5} / \mathrm{ha}+40 \mathrm{Kg} / \mathrm{ha} \mathrm{K} \mathrm{K}_{2} \mathrm{O}$ mineral fertilizers have generated reshaped acid soils with agrochemical properties close to average fertile soils. These new soils have promoted intensive vegetative growth in maize plants (waist, green mass and dried mass), as well as the high productions in cobs and grains. Harvested green mass, and cobs and grains contain macronutrients, micronutrients and heavy metals at normal concentration, usually found in maize.
\end{abstract}

Keywords: bauxite residue, Albota acid soil, organic compost, maize, soil remediation, soil reshaping.

DOI: 10.17516/1998-2836-0001.

(c) Siberian Federal University. All rights reserved

* Corresponding author E-mail address: 1cotet@alum.ro 


\title{
Безопасное захоронение бокситовых отходов \\ и возможности дальнейшего применения. \\ Часть 1. Рекультивация кислотных почв
}

\author{
Джордж Добра, Лауренциу Филипеску, \\ Николае Ангеловичи, Викол Алистарх, \\ Сорин Илиев, Лучиан Котет \\ VIMETCO ALUM SA \\ Румьиния, 820228, Тулча, Isaccei Str., 82
}

Статья представляет исследования, касающиеся нового подхода в рекультивации кислотных почв путем восстановления поверхностного слоя земли для изменения его агрохимического состава и свойств. Для этого были использованы три вспомогательных вещества при контроле качества земли: отходы бокситов для контроля рН, органический компост как источник органического углерода и лучшего контроля свойств почв и минеральные удобрения NPK как источник основных макроэлементов. Значения 15, 30 и 75 m отходов бокситов на 1 га соответствуют $40 \mathrm{~m} / 2$ органического компоста и $120 \mathrm{\kappa z} \mathrm{N/2а}+60 \kappa 2 \mathrm{P}_{2} \mathrm{O}_{5} / \Gamma a+$ 40 кг/Га $K_{2} O$ минеральных удобрений, сформировавших восстановленную кислотную почву, с агрохимическими свойствами, близкими к средним свойствам плодородной почвы. Эта новая почва способствовала интенсивному росту кукурузы (оценивали параметры: узкая часть початка, зеленая масса и высушенная масса), а также высокая продуктивность початка и зерен. Собранные зеленая масса, початки и зерна содержат макроэлементы, микроэлементы и тяжелье металль, соответствующче нормальной концентрации, содержащуейся в обычной кукурузе.

Ключевые слова: отходы бокситов, кислотные почвы, органический компост, кукуруза, рекультивация почвы, восстановление почвы.

\section{Introduction}

After 2009 retrofit of the landfill site at Vimetco Alum SA Tulcea refinery and significant improvements brought by switching from bauxite residue sludge lagoon impoundment to deep thickening and disposal in dry state, the dried bauxite residue disposal site met the terms of main EU directives recommendation regarding environmental protection. During the retrofit of landfill site and afterward, many noteworthy works were carried out for the sake of investment consolidation [1]. Thus, the environmental risks have been considerably reduced compared to previous applied technology for dumping the bauxite residue, and the disposal site environmental impact on the surrounding agricultural area is not significant anymore.

Since 2011 Vimetco Alum SA Tulcea was using predominantly the bauxite originating from Sierra Leone. From thenceforth, the factory accumulated a good experience in processing this type of bauxite and started some projects carried out in its laboratory or in cooperation with other Romanian research 
institutes, trying to find new applications for the well characterized bauxite residue (bauxite residue chemical/mineralogical analysis and physical properties, new measurements of radioactivity, heavy metal content, composition and properties of the minimal processed bauxite residue at the disposal site location, and toxicity/irritation and dermal corrosivity thresholds) [1]. Many studies underlined that the bauxite residue application to any soil is very effective for reducing the phosphorous leaching, improving the pasture growth, ameliorating the soil acidity, increasing the plant metal sorption and decreasing the soluble metals concentration, and above all, the bauxite residue reduces the heavy metals availability [2-7]. But, the acid soil rehabilitation with bauxite residue is not just a simple problem of mixing and dispersing. The simple addition of bauxite residue to soils involves increases in $\mathrm{pH}$, in total dissolved solids (TDS), in dissolved organic compounds (DOC), as well as some raises in the concentrations of oxy-anion-forming heavy metals in the soil solutions. The extent of these changes depends highly on the final mixture $\mathrm{pH}$ and also, on the soil natural or induced buffering capacity. It should be avoided the $\mathrm{pH}$ values above 8.5-9.0 (promoting some larger increases in the concentrations of aluminium, vanadium and arsenic), as well as the low organic carbon and high clay content (promoting the heavy metal mobilization). This is the reason for the bauxite residue association with other materials rich in organic carbon [1-7].

Researches concerning the uses of bauxite residue in agriculture could be classified according to their disclosed specific purposes into two main groups: a) deep reshaping of the bauxite residue composition, capping and revegetation; b) change of the soils chemistry by bauxite residue metal immobilization and acid soils remediation. The common strategies for reaching these purposes are including: amendments of gypsum for reducing $\mathrm{pH}$, balancing the sodicity, alkalinity, aluminum toxicity and improving porosity, and amendments of sand, clay or other materials for changing the water holding capacity of bauxite residue, Also, amendments of organic and inorganic fertilizers, supplied for providing minimal mineral nutrition and amelioration of $\mathrm{C} / \mathrm{N}$ ratio are highly required. Additionally, in situ chemical immobilization provides several specific chemical additives to any particularly contaminated soil, recommended for changing the chemical speciation, mobility and bioavailability of heavy metals or for promoting the precipitation or co-precipitation, absorption and complexion, ion exchange, etc., all for the full incorporation of heavy metals into very safety inert compounds. Some of these strategies were adopted by SC Alum SA Tulcea in cooperation with INCDPAPM-ICPA Bucharest for tailoring some suiTable bauxite residue composite materials by deep changes in the bauxite residue composition from their formulations. The experiments, carried out after 2011, were directed to studies concerning the accommodation of different species from spontaneous flora or common cultivated species to some soil formulations containing bauxite residue. The results were partially published in the papers [1, 8-11]. Several promising results came from the maize plants, cultivated on type of soils related to acid soils rehabilitation strategy [1]. Thus, the researchers were extended with a new study concerning the weathered bauxite residue use as an alkaline adjuvant for acid soils rehabilitation in a new approach, mainly by deep change in the soil structure and composition, and eventually its conversion into a soil with average fertility. This study is not a simple test carried out in order to improve the acid soils fertility, but rather a planned work for deep changes in all the agrochemical properties of any particular acid soil, using bauxite residue in well adjusted ratios with organic composts and mineral fertilizers for inducing in the soil surface layer most of the specific properties of medium fertility soils. 
In this paper there are reported the data of a full experiment carried out at glasshouse scale with the maize plants growth on a well balanced formulation of deep reshaped soil, containing mixtures between acid soil, bauxite residue, natural compost carrying organic fertilizers and organic carbon and mineral fertilizers carrying total soluble nitrogen, phosphorus and potassium.

\section{Experimental part}

\subsection{Methods and analyses}

All the chemical and mineralogical analyses were made according to the ISO standards and Romanian standards issued after 2006 or Romanian harmonized standards and technical specifications recognized in UE. The other methods applied for measuring composition and properties of the bauxite residue, of the soil before and after remediation, of the organic compost and mineral fertilizers and of the other connected products have been chosen from the recommended literature in the field of chemistry and chemical engineering. Because of diversity and number of these methods, they will be described or nominated as providing source, together with the experimental data presentation.

\subsection{Materials}

Component 1. Raw bauxite residue. The raw bauxite residue samples were collected from the areas covered after 2011 and the best choice were the dried areas of disposal site, opposite to the main dam. During the experiments there were use two type of samples. The first was taken from the recently accumulated material (row bauxite residue) and second type from the evidently weathered material originating from older layers with a composition close to the most of material discharged into disposal site between 2005 and 2011. The first type of sampled bauxite residue was used for chemical and mineralogical analysis, chemical and physical properties evaluation, measurements of radioactivity and heavy metal content and respectively, for assessment of the acute toxicity/irritation. All the data concerning this particular type of bauxite residue, representing $10 \%$ of the entire stockpiled material, were presented in the papers [1, 12]. The second type of sampled bauxite residue, representing $90 \%$ of the entire stockpiled material, was used for studies on the deep changing of bauxite residue chemical properties and evaluation of the minimal required treatments for using it as remediation adjuvant for acid soils or for converting the bauxite residue into commercial products. The results of the previous researches carried out with this type of material have been published in the papers [7-11].

In the Tables 1-8 there are given all the data about the bauxite residue composition and its particular features, identified as main indicators in reshaping bauxite residue as a remediant in acid soil rehabilitation. The bauxite residue particle size distribution (Table 1) is well fitted for the mixing, firstly with any acid soil, and secondly with other components (organic composts and mineral ferilizers), required for a proper reshaping of its properties at any stage of the remediation process. When compared with the common soils composition, the bauxite residue elemental composition is largely different, mainly from the point of view of macro and mezzo nutrient contents $(\mathrm{N}, \mathrm{P}$ and $\mathrm{K}$, as well as soluble $\mathrm{Ca}$ and soluble $\mathrm{Mg}$ ) (Table 2, 3).

The heavy metals measured concentrations are in good agreement with other refineries data (Table 4). Notably, the Romanian bauxite residues type 1 and type 2 do not contain arsenic and mercury, and the cadmium, nickel and lead were found at substantial lower concentrations. Chromium concentration should be cautiously ascertained, because our previous data have shown the leachable 
Table 1. Bauxite residue particle size distribution

\begin{tabular}{|c|c|c|c|c|c|c|}
\hline $\begin{array}{c}\text { Particle size dimensions, } \\
\mathrm{mm}\end{array}$ & $2.0-0.2$ & $0.2-0.02$ & $0.02-0.002$ & $>0.002$ & $>0.001$ & Total \\
\hline Content, \% & 58.6 & 24.4 & 15.8 & 1.0 & 0.2 & 100 \\
\hline
\end{tabular}

Table 2. Chemical analysis of the bauxite residue from SC Alum SA Tulcea (XRF analysis)

\begin{tabular}{|l|c|c|c|c|c|c|c|c|c|c|}
\hline Compunds, \% & $\mathrm{Al}_{2} \mathrm{O}_{3}$ & $\mathrm{CaO}$ & $\mathrm{MgO}$ & $\mathrm{K}_{2} \mathrm{O}$ & $\mathrm{Na}_{2} \mathrm{O}$ & $\mathrm{SiO}_{2}$ & $\mathrm{Fe}_{2} \mathrm{O}_{3}$ & $\mathrm{MnO}^{2}$ & $\mathrm{TiO}_{2}$ & $\mathrm{PC}$ \\
\hline Bauxite residue (type 1) & 18.2 & 3.7 & 0.2 & 0.2 & 6.9 & 7.5 & 44.6 & 0.1 & 3.2 & 15.6 \\
\hline Bauxite residue (type 2) & 19.5 & 4.9 & - & - & 3.4 & 9.3 & 46.0 & - & 2.3 & 14.6 \\
\hline Total content $=100 \%$
\end{tabular}

Table 3. The $\mathrm{pH}$ and organic carbon, macronutrients and micronutrients in bauxite residue, organic compost and Albota acid soil, and other average ferility soils from Romania

\begin{tabular}{|l|c|c|c|c|c|c|c|}
\hline \multicolumn{1}{|c|}{ Main components } & $\mathrm{pH}$ & $\mathrm{C}_{\mathrm{ORG}}, \%$ & $\mathrm{~N}, \%$ & $\mathrm{P}, \%$ & $\mathrm{~K}, \%$ & $\mathrm{Ca}, \%$ & $\mathrm{Mg}, \%$ \\
\hline Bauxite residue (type 2) & 12.08 & 0.626 & 0.02 & 0.092 & 0.12 & 2.610 & 0.009 \\
\hline Organic compost & 7.13 & 9.200 & 1.16 & 0.600 & 1.14 & 3.000 & 1.200 \\
\hline Albota acid soil & 5.29 & 1.920 & 0.180 & 0.005 & 0.45 & 0.670 & 1.020 \\
\hline $\begin{array}{l}\text { Sandy cernozem, Bailesti, Romania } \\
\text { [20] }\end{array}$ & 7.90 & 2.11 & 0.105 & 0.05 & 0.09 & 1.24 & 1.90 \\
\hline Cernozem, Banat, Romania [21] & 6.19 & 2.19 & 1.92 & 0.02 & 0.11 & 3.15 & 1.55 \\
\hline
\end{tabular}

Table 4. Micronutrients and heavy metals in bauxite residue, organic compost and Albota acid soil

\begin{tabular}{|l|c|c|c|c|c|c|c|c|c|c|c|}
\hline \multicolumn{1}{|c|}{ Elements, $\mathrm{mg} / \mathrm{Kg}$} & $\mathrm{Cd}$ & $\mathrm{Co}$ & $\mathrm{Cr}$ & $\mathrm{Cu}$ & $\mathrm{Fe}$ & $\mathrm{Mn}$ & $\mathrm{Ni}$ & $\mathrm{Pb}$ & $\mathrm{Zn}$ & $\mathrm{As}$ & $\mathrm{Hg}$ \\
\hline $\begin{array}{l}\text { Bauxite residue } \\
\text { (type 2) }\end{array}$ & 0 & 9.8 & 604 & 68.7 & 276481 & 206 & 15.1 & 49.0 & 24.0 & 0 & 0 \\
\hline $\begin{array}{l}\text { Bauxite residue } \\
\text { (type 1) }\end{array}$ & 0.05 & - & 676 & 89.6 & - & - & - & 7.24 & 46.6 & 0 & 0 \\
\hline Bauxite rezidue (others) & 27.0 & - & 538 & 78.0 & - & - & 98.5 & 57.0 & - & 27 & 67 \\
\hline Organic compost & 0.36 & 4.1 & 17.2 & 31.0 & 12843 & 437 & 22.0 & 22.0 & 116 & 0 & 0 \\
\hline Albota acid soil & 0.13 & 15 & 22.8 & 12.6 & 2.8 & 1370 & 15.6 & - & 66.8 & - & - \\
\hline
\end{tabular}

parts of chromium are decreasing under the accep Table standards, as far as the $\mathrm{pH}$ drops toward the usual values found in normal soils $[13,14]$. Total soluble salt content found in the composition of bauxite residue type 2 was 1525/1836 mg per $100 \mathrm{~g}$ dry material (Table 5). This value is 18 times higher than the limit of $100 \mathrm{mg}$ soluble salts per $100 \mathrm{~g}$ soil, accepted as minimum value from which the soil salinity begins to damage plant growth processes (Table 5). Expected prevalence of $\mathrm{CO}_{3}(2-)$ and $\mathrm{Na}(1+)$ ions in the soluble salt content, mainly as $\mathrm{Na}_{2} \mathrm{CO}_{3}$ (Table 6), was obviously recorded [8, 9]. This gives 
specificity to the total soluble salts parameter and it is a certain proof of the bauxite residue weathering. But, the real problem of bauxite residue conversion into fertile soils is the high level of $\mathrm{Na}(1+)(5300$ $\mathrm{mg} / \mathrm{kg})$ and $\mathrm{Ca}(2+)(2800 \mathrm{mg} / \mathrm{kg})$ ionic mobility [8,9]. Only the mobilities of phosphorus (about 200 $\mathrm{mg} / \mathrm{kg}$ ) and potassium (about $300 \mathrm{mg} / \mathrm{kg}$ ) (Table 8) seem to be appropriate values for sustaining the plant growth, as happens in the common soils.

For alumina refineries, an advanced technology for sodium removal from bauxite residue is a problem of efficiency and production costs. In any future plan this technology could be reconsidered

Table 5. Dry residue and soluble ionic salts content in component 1 and component 2

\begin{tabular}{|l|c|c|}
\hline \multicolumn{1}{|c|}{ Parameter } & Bauxite residue & Organic compost \\
\hline Dry residue, $\mathrm{mg} / 100 \mathrm{~g}$ & 1525.0 & 540.0 \\
\hline Conductometric value, $\mathrm{g} / 100 \mathrm{~g}$ & 1836.0 & 992.0 \\
\hline $\mathrm{NO}_{3}(1-), \mathrm{mg} / 100 \mathrm{~g}$ & - & 179.0 \\
\hline $\mathrm{CO}_{3}(2-), \mathrm{mg} / 100 \mathrm{~g}$ & 704.0 & - \\
\hline $\mathrm{HCO}_{3}(1-), \mathrm{mg} / 100 \mathrm{~g}$ & 64.3 & 38.0 \\
\hline $\mathrm{SO}_{4}(2-), \mathrm{mg} / 100 \mathrm{~g}$ & 19.0 & 37.6 \\
\hline $\mathrm{Cl}(1-), \mathrm{mg} / 100 \mathrm{~g}$ & 32.0 & 52.0 \\
\hline $\mathrm{Ca}(2+), \mathrm{mg} / 100 \mathrm{~g}$ & 1.0 & 34.6 \\
\hline $\mathrm{Mg}(2+), \mathrm{mg} / 100 \mathrm{~g}$ & - & 28.6 \\
\hline $\mathrm{Na}(1+), \mathrm{mg} / 100 \mathrm{~g}$ & 609.0 & 264.0 \\
\hline $\mathrm{K}(1+), \mathrm{mg} / 100 \mathrm{~g}$ & 6.0 & \\
\hline
\end{tabular}

Table 6. Formal molecular saline compounds in component 1 and component 2

\begin{tabular}{|l|c|c|}
\hline \multicolumn{1}{|c|}{ Parameter } & Bauxite residue (Type 2) & Organic compost \\
\hline $\mathrm{Na}_{2} \mathrm{CO}, \%$ & 91.9 & 2.7 \\
\hline $\mathrm{NaHCO}_{3}, \%$ & 3.4 & 19.2 \\
\hline $\mathrm{CaHCO}_{3}, \%$ & 0.2 & 21.1 \\
\hline $\mathrm{MgHCO}_{3}, \%$ & - & 6.5 \\
\hline $\mathrm{Na}_{2} \mathrm{SO}_{4}, \%$ & 1.4 & - \\
\hline $\mathrm{NaCl}_{0}$ & 2.5 & 32.5 \\
\hline $\mathrm{KCl}_{0} \%$ & 0.6 & 18.0 \\
\hline $\mathrm{K}_{2} \mathrm{SO}_{4}, \%$ & - & 100 \\
\hline Total & 100.0 & \\
\hline
\end{tabular}

Table 7. Agrochemical composition of the component 1 and component 2

\begin{tabular}{|l|c|c|c|c|c|c|c|c|}
\hline \multicolumn{1}{|c|}{ Parameter } & $\begin{array}{c}\mathrm{pH} \\
\left(\mathrm{H}_{2} \mathrm{O}\right)\end{array}$ & $\mathrm{C}_{\mathrm{ORG}} \%$ & $\begin{array}{c}\text { Organic } \\
\text { matter, \%. }\end{array}$ & $\begin{array}{c}\text { Total } \\
\mathrm{N}_{\mathrm{t}, \%}\end{array}$ & $\begin{array}{c}\mathrm{C} / \mathrm{N} \\
\text { ratio }\end{array}$ & $\begin{array}{c}\mathrm{N}^{-\mathrm{NO}_{3}} \\
\mathrm{mg} / \mathrm{Kg}\end{array}$ & $\begin{array}{c}\mathrm{P}\left(\mathrm{H}_{2} \mathrm{O}\right) \\
\mathrm{mg} / \mathrm{Kg}\end{array}$ & $\begin{array}{c}\mathrm{K}\left(\mathrm{H}_{2} \mathrm{O}\right) \\
\mathrm{mg} / \mathrm{Kg}\end{array}$ \\
\hline Bauxite residue (type 2) & 12.80 & 0.626 & - & 0.616 & 45.5 & - & 216.0 & 173 \\
\hline Organic compost & 7.35 & 25.6 & 68 & 1.34 & 22.3 & 65 & 12.8 & 470 \\
\hline
\end{tabular}


Table 8. Bauxite residue (type 2) agrochemical properties

\begin{tabular}{|c|c|c|c|c|c|}
\hline Ionic mobility & $\begin{array}{c}\text { Values, } \\
\mathrm{mg} / \mathrm{Kg}\end{array}$ & $\begin{array}{c}\text { Ion exchange } \\
\text { capacity }\end{array}$ & $\begin{array}{c}\text { Values, } \\
\text { meq./100g }\end{array}$ & $\begin{array}{c}\text { Total ion } \\
\text { exchange capacity }\end{array}$ & $\begin{array}{c}\text { Values, } \\
\text { meq./100g }\end{array}$ \\
\hline $\mathrm{P}_{\mathrm{AL}}$ & 196 & $\mathrm{Na}$ la $\mathrm{pH} 7$ & 128.63 & $\mathrm{~T}_{\mathrm{Na}}$ & 62.58 \\
\hline $\mathrm{K}_{\mathrm{AL}}$ & 287 & $\mathrm{Na}$ in water & 26.45 & $\mathrm{~T}_{\mathrm{NH} 4}$ & 29.48 \\
\hline & & Exchangeable Na & 100.15 & - & - \\
\hline
\end{tabular}

as feasible in the alumina refineries, not only as a problem of materials consumption optimization, but also as a way to improve bauxite residue quality for its further processing to some secondary products. According to the bauxite residue agrochemical composition and properties, the non-processed material could not be used for any agricultural purpose (Table 7,8), due to the low content in macronutrients (nitrogen, phosphorus and potassium) and organic carbon (Table 7), as well as due to the poor agrochemical properties (Table 8). Beside the bauxite residue dry landfill and weathering, parts of mobile $\mathrm{Na}(1+)$ and $\mathrm{Ca}(2+)$ ions could be removed by air carbonation of the isolated bauxite residue piles, followed by over-weathering stages under pluvial water washings and natural temperature variations over long time periods.

Component 2. Organic compost. The organic compost chemical and agrochemical composition and properties are presented in the Tables 3, 4, 7. According to these Tables, the organic compost is neutral - slightly basic material ( $\mathrm{pH} 7.35$, Tables 3, 7). Its content in organic matter and organic carbon is high, but the content in total nitrogen is low (Tables 3,7). The mobile nitrogen as nitrate is high, close to the upper limits usually found in horticultural soils. Also, the supply with hydro-soluble phosphorus is medium for organic composts, but the supply with potassium is very high (Table 7). Some reserves in ionic calcium and magnesium can be seen in the Table 3. Calcium reserves were found at the same level as in bauxite residue and magnesium reserves, at the same level as in Albota acid soil. Both bauxite residue and organic compost are carrying important quantities of soluble salts and heavy metals (Table 4).

Component 3. Mineral fertilizers. It should be noted that the organic compost could help to control the soil quality, but it does nothing to feed the crops. For inducing a standard medium fertility in the reshaped soil, according to this experiment, it is all-important to bring in the reshaped soil mineral fertilizers, able to deliver significant quantities of nitrogen, phosphorus and potassium without any significant interference with the soil chemical composition. The best choice of mineral fertilization was a mixture of ammonium nitrate and potassium hydrogen phosphate with formula $\mathrm{N}_{120} \mathrm{P}_{60} \mathrm{~K}_{40}$ (i.e. 120, 60 and $40 \mathrm{~kg} / \mathrm{ha}$ ). Full solubility of this formula supplies the reshaped soil with the same macronutrients missing from bauxite residue, organic compost and Albota acid soil. Moreover, most parts from these macronutrients are assimilated or lost, leaving behind little quantities of nitrogen, phosphorus and potassium, which are enriching the soil quality after the crop harvesting.

Component 4. Albota acidic soil. Chemical and agrochemical properties of the Albota acidic soil are presented in the Tables 2, 4 and 9. As illustrated in Table 3, the Albota acid soil is a very low fertility soil, missing large reserves of maconuterients and mezzonutrients. Also, this soil is carrying significant concentations of cobalt, chromium, manganese and zinc. The Albota albic luvosoil is a typical acid soil with moderate $\mathrm{pH}$, controlled by its low to medium bases saturation $\left(\mathrm{V}_{\mathrm{Ah}}\right)$, specific 
Table 9. Agrochemical properties of the upper horizons in Albota albic luvosoil (Arges county)

\begin{tabular}{|c|c|c|c|c|c|c|c|c|c|c|}
\hline $\mathrm{D}$ & $\mathrm{pH}\left(\mathrm{H}_{2} \mathrm{O}\right)$ & $\mathrm{SB}$ & $\mathrm{A}_{\mathrm{h}}$ & $\mathrm{V}_{\mathrm{Ah}}$ & $\mathrm{N}_{\mathrm{t}}$ & $\mathrm{N}_{-N \mathrm{NO}_{3}}$ & $\mathrm{Hum}$ & $\mathrm{P}_{\mathrm{t}}$ & $\mathrm{P}_{\mathrm{AL}}$ & $\mathrm{K}_{\mathrm{AL}}$ \\
\hline $0-20$ & 5.10 & 10.06 & 5.86 & 63.2 & 0.100 & 9.0 & 1.98 & 0.047 & 14.3 & 92 \\
\hline $20-40$ & 5.31 & 10.94 & 5.11 & 68.2 & 0.094 & 7.5 & 1.86 & 0.045 & 13.0 & 100 \\
\hline
\end{tabular}

D - Soil layer depth, cm; SB - Total exchangeble bases, meq/100 g; $\mathrm{A}_{\mathrm{h}}-$ Medium bases saturation, meq/100 $\mathrm{g}$; $\mathrm{V}_{\mathrm{Ah}}-$ Degree of saturation with bases, $\% ; \mathrm{N}_{\mathrm{t}}$ - total nitrogen, $\% ; \mathrm{N}_{\mathrm{NO}}$ - nitric nitrogen, $\%$; Hum - Humus, $\% ; \mathrm{P}_{\mathrm{t}}-$ Total phosphorus, $\% ; \mathrm{P}_{\mathrm{AL}}-$ Phosphorus ionic mobility, $\mathrm{mg} / \mathrm{kg} ; \mathrm{K}_{\mathrm{AL}}-$ Potassium ionic mobility, $\mathrm{mg} \cdot \mathrm{kg}$.

for oligo-mezo-basic soils. Its medium hydrolytic acidity (Ah) and low trophic level are due to its poor content in exchangeable bases $(\mathrm{SB})$, humus, total nitrogen $(\mathrm{Nt})$, nitric nitrogen $(\mathrm{N}-\mathrm{NO})$, mobile phosphorus $\left(\mathrm{P}_{\mathrm{AL}}\right.$, ) and mobile potassium $\left(\mathrm{K}_{\mathrm{AL}}\right.$ ) (Table 9). All data are in good with the reference literature [15-19]. For better understanding the nature a Albota luvosoil soils, in the Table 3 there is presented the chemical composition of two types of cernozem from Romania [21, 22].

Due to its well known particularities, the Albota albic luvosoil from Albota (Arges) Romania was considered a representative acid soil to be remediated according to the proposed technology. All main components (bauxite residue, organic compost and Albota acidic soil) are carrying important quantities of soluble salts and heavy metals (Table 4). Thus, the careful formulation of the deep reshaped soils composition had to reach two main targets: a) alleviation of these compounds effect on the reshaped soil quality and b) preservation of the plants health and the crop quality during experiment.

\subsection{Experimental set up}

The entire experiment was carried out under three preliminary restrictions: a) All components in all the soil formulations are well mixed, approximating an even distribution of chemical composition and agrochemical properties; b) The homogenized soils are simulating results of a well done plowing of Albota acid soil from the upper surface horizon $(0-20 \mathrm{~cm})$, after a prior surface dispersion of the three adjuvant components; c) During the vegetation stages, there will be maintained a relative humidity equal to $70 \%$ of water capacity of the soil, independently of the soil composition. Experimental set up with 6 variants (Table 10) was started at 16 July 2012. The experiment comprises 3 repetitions for each variant using vegetation pots with a capacity of $8 \mathrm{~kg}$ soil, following the basic procedures of INCDPAPM-ICPA Bucharest, shortly described in the papers [9, 10, 22-24]. During the growing season, in addition to maintaining steady growth factors, there were made observations regarding the emergence (percentage of emerged plants in dynamics), plant height (in dynamics), and morphological aspects (emergence of various phenomena such as chlorosis, stagnation in growth, leaf necrosis, etc.).

At the end of growing season, set up in a different way from one experience to another, there were taken plant samples for measuring the green and dry mass of aerial parts and root parts. Also, there were made typical chemical analysis for plants and grains. During vegetation stages there were made measurements on plants waist till the harvesting day, and two plant thinning on 30 July and 20 August 2012. Also, at the end the growing season were taken soil samples. Both sets of samples were measured and analyzed, according to the INCDPAPM-ICPA Bucharest methodology [22-24]. The applied analytical methods were the well known ISO European methods. All analytical data were statistically calculated using statistical parameters and variance analysis. For the interpretation of the 
Table 10. Experimental variants

\begin{tabular}{|c|c|}
\hline $\begin{array}{l}\text { Experimental } \\
\text { variants }\end{array}$ & Composition \\
\hline 1 & Control 1; Non-ammended; Non-fertilized \\
\hline 2 & Control 2; Non-ammended; Organic fertilization -40 t/ha \\
\hline 3 & Control 3; Non-ammended; Organic fertilization -80 t/ha \\
\hline 4 & $\begin{array}{l}\text { Bauxite residue ammended - } 15 \mathrm{t} / \mathrm{ha} \text {; Organic fertilization }-40 \mathrm{t} / \mathrm{ha} \text {; Mineral } \\
\text { fertilization }-\mathrm{N}_{120} \mathrm{P}_{60} \mathrm{~K}_{40}\left(120 \mathrm{Kg} \mathrm{N} / \mathrm{ha}+60 \mathrm{Kg} \mathrm{P} \mathrm{O}_{5} / \mathrm{ha}+40 \mathrm{Kg} / \mathrm{ha} \mathrm{K} \mathrm{K}_{2} \mathrm{O}\right)\end{array}$ \\
\hline 5 & $\begin{array}{l}\text { Bauxite residue ammended - } 30 \mathrm{t} / \mathrm{ha} \text {; Organic fertilization }-40 \mathrm{t} / \mathrm{ha} \text {; Mineral } \\
\text { fertilization }-\mathrm{N}_{120} \mathrm{P}_{60} \mathrm{~K}_{40}\left(120 \mathrm{Kg} \mathrm{N} / \mathrm{ha}+60 \mathrm{Kg} \mathrm{P} \mathrm{O}_{5} / \mathrm{ha}+40 \mathrm{Kg} / \mathrm{ha} \mathrm{K} \mathrm{K}_{2} \mathrm{O}\right)\end{array}$ \\
\hline 6 & $\begin{array}{l}\text { Bauxite residue ammended }-75 \mathrm{t} / \mathrm{ha} \text {; Organic fertilization }-40 \mathrm{t} / \mathrm{ha} \text {; Mineral } \\
\text { fertilization }-\mathrm{N}_{120} \mathrm{P}_{60} \mathrm{~K}_{40}\left(120 \mathrm{Kg} \mathrm{N} / \mathrm{ha}+60 \mathrm{Kg} \mathrm{P} \mathrm{O}_{5} / \mathrm{ha}+40 \mathrm{Kg} / \mathrm{ha} \mathrm{K} \mathrm{K}_{2} \mathrm{O}\right)\end{array}$ \\
\hline
\end{tabular}

obtained data there was used the current methodology practiced by INCDPAPM-ICPA Bucharest, based on the papers [23, 24].

\section{Results}

\subsection{Chemical analysis and properties of the soil from experimental variants}

Analytical data on the soil chemistry in the experimental variants are given in Table 11. From this Table, it can be seen that the reaction of Albota on-amended soil is moderately acid $\left(\mathrm{pH}\left(\mathrm{H}_{2} \mathrm{O}\right)=5.1\right)$. By amending this soil with regular doses of bauxite residue, organic compost and mineral fertilizers (Table 11), the soil $\mathrm{pH}$ is proportionally rising up till level of the low basic soils. Also, by amending the regular doses of bauxite residue, organic compost and mineral fertilizers according the Table 10, a lot of changes were yielded in soil chemistry, as well as in its agrochemical properties (Table 11, 12). Roughly, beside the $\mathrm{pH}$ raise to a slightly alkaline reaction, the amendments have improved the content of organic $\mathrm{C}$ and total $\mathrm{N}$ and, at moderate doses of organic compost, there has been raised the mobility of ions $\mathrm{P}$ and $\mathrm{K}$, too. Thus, the total exchangeable bases (SB), degree of bases saturation $\left(\mathrm{V}_{\mathrm{Ah}}, \%\right)$ and the total capacity of cationic exchange were substantially raised, and the hydrolytic acidity recorded earnest diminutions (Table 11, 12). Moreover, the total soluble salts content (TSS) dropped below the critical level of $100 \mathrm{mg} / 100 \mathrm{~g}$ (Table 11).

After harvesting, the soils have preserved some of the acquired changes in their properties, due to the applied amendments. Composition and agrochemical properties of the depleted soil after harvesting are given in the Table 13. Content of the heavy metals including micronutrients in the studied soils (variants) is given in the Table 14. According to these data, the amendments have properly balanced the heavy metal content of all the tested soils (variants), raising evidently quality of the remediated Albota acid soils. The values in the Table 14 are in good agreement with heavy metal content in the usual soils.

\subsection{Crop measurements during the vegetative growth stages}

\section{and harvest characterization}

There were measured the following parameters of the plants organs: the plant waist, the leaves weight, the stems weight, the roots weight, the husks weight, and the cobs and grains weight. Also, 
Table 11. Agrochemical composition of the tested soils before experiments

\begin{tabular}{|l|c|c|c|c|c|c|c|c|c|}
\hline \multicolumn{1}{|c|}{ Variants } & $\mathrm{pH}$ & Humus, $\%$ & $\mathrm{C}_{\mathrm{ORG}} \%$ & $\begin{array}{c}\mathrm{Nt}, \\
\%\end{array}$ & $\mathrm{C} / \mathrm{N}$ & $\begin{array}{c}\mathrm{N}^{2} \mathrm{NO}_{3}, \\
\mathrm{mg} / \mathrm{Kg}\end{array}$ & $\begin{array}{c}\mathrm{P}_{\mathrm{Al}} \mathrm{mg} / \\
\mathrm{Kg}\end{array}$ & $\begin{array}{c}\mathrm{K}_{\mathrm{AL}}, \\
\mathrm{mg} / \mathrm{Kg}\end{array}$ & $\begin{array}{c}\mathrm{TSS}, \\
\mathrm{mg} / 100 \mathrm{~g}\end{array}$ \\
\hline Variant V1 & 5.10 & 1.98 & 1.53 & 0.136 & 4.6 & 13.2 & 14.0 & 65.0 & 24 \\
\hline Variant V2 & 6.64 & 15.28 & 8.9 & 0.246 & 41.9 & 1.0 & 41.0 & 187.0 & 25 \\
\hline Variant V3 & 6.45 & 11.28 & 6.5 & 0.227 & 33.7 & 4,0 & 57.0 & 278.0 & 34 \\
\hline Variant V4 & 6.79 & 11.20 & 6.5 & 0.224 & 33.8 & 1.0 & 45.0 & 172.0 & 37 \\
\hline Variant V5 & 7.07 & 12.08 & 7.0 & 0.239 & 34.3 & 37.0 & 39.0 & 320.0 & 40 \\
\hline Variant V6 & 7.29 & 15.12 & 8.8 & 0.218 & 46.9 & 1.0 & 37.0 & 196.0 & 58 \\
\hline DL 5\% & 0.18 & - & 1 & 0.018 & 5.8 & 2.9 & 5.0 & 19.0 & 16 \\
\hline
\end{tabular}

Table 12. Agrochemical properties of the tested soil formulations

\begin{tabular}{|c|c|c|c|c|}
\hline Variants & SB, meq/100 g & Ah, meq/100 g & T. meq/100 g & VAh. \% \\
\hline Variants 1 & 10.60 & 5.86 & 15.6 & 63.8 \\
\hline Variant 2 & 11.89 & 5.29 & 17.18 & 69.2 \\
\hline Variant 3 & 14.63 & 4.35 & 18.97 & 77.4 \\
\hline Variant 4 & 14.50 & 5.53 & 20.02 & 72.4 \\
\hline Variant 5 & 15.02 & 4.33 & 19.35 & 77.6 \\
\hline Variant 6 & 18.30 & 2.19 & 20.50 & 3.0 \\
\hline DL 5\% & 1.17 & 0.62 & 1.23 & 4.1 \\
\hline DL 1\% & 1.61 & 0.85 & 1.70 & 5.7 \\
\hline DL 0.1\% & 2.22 & 1.17 & 2.23 & 3.0 \\
\hline
\end{tabular}

$\mathrm{SB}$ - Total exchangeble bases; $\mathrm{A}_{\mathrm{h}}$ - Medium bases saturation; $\mathrm{T}$ - Total ion exchange capacity; $\mathrm{V}_{\mathrm{Ah}}-$ Degree of saturation with bases.

Table 13. Agro-chemical composition of the tested soils after harvest

\begin{tabular}{|c|c|c|c|c|c|c|}
\hline Variants & $\mathrm{pH}$ & Humus, \% & CORG, \% & $\mathrm{Nt}, \%$ & $\mathrm{C} / \mathrm{N}$ & $\begin{array}{c}\text { N-NO3, } \\
\mathrm{mg} / \mathrm{Kg}\end{array}$ \\
\hline V1 & 5.11 & 1.53 & 0.138 & 13.3 & 24 & 89 \\
\hline V2 & 5.29 & 1.90 & 0.144 & 15.4 & 33 & 81 \\
\hline V3 & 5.57 & 2.05 & 0.154 & 15.6 & 29 & 75 \\
\hline V4 & 5.66 & 1.80 & 0.141 & 14.9 & 130 & 128 \\
\hline V5 & 5.90 & 177 & 0.157 & 13.2 & 180 & 119 \\
\hline V6 & 6.72 & 1.77 & 0.193 & 10.7 & 258 & 172 \\
\hline DL 5\% & 0.17 & 0.20 & 0.05 & 0.16 & 15 & 18 \\
\hline
\end{tabular}


Table 14. Micronutrients and heavy metals in the tested soils (variants)

\begin{tabular}{|c|c|c|c|c|c|c|c|c|}
\hline Variants & $\begin{array}{c}\mathrm{Cd}, \\
\mathrm{mg} / \mathrm{Kg}\end{array}$ & $\begin{array}{c}\mathrm{Co}, \\
\mathrm{mg} / \mathrm{Kg}\end{array}$ & $\begin{array}{c}\mathrm{Cr}, \\
\mathrm{mg} / \mathrm{Kg}\end{array}$ & $\begin{array}{c}\mathrm{Cu}, \\
\mathrm{mg} / \mathrm{Kg}\end{array}$ & $\begin{array}{c}\mathrm{Fe}, \\
\mathrm{mg} / \mathrm{Kg}\end{array}$ & $\begin{array}{c}\mathrm{Mn}, \\
\mathrm{mg} / \mathrm{Kg}\end{array}$ & $\begin{array}{c}\mathrm{Ni}, \\
\mathrm{mg} / \mathrm{Kg}\end{array}$ & $\begin{array}{c}\mathrm{Zn}, \\
\mathrm{mg} / \mathrm{Kg}\end{array}$ \\
\hline Variant 1 & 0.131 & 14.9 & 22.8 & 12.6 & 2.81 & 1370.0 & 15.6 & 65.7 \\
\hline Variant 2 & 0.137 & 14.6 & 24.4 & 12.0 & 2.61 & 1229.0 & 15.3 & 59.7 \\
\hline Variant 3 & 0.141 & 18.6 & 24.1 & 12.5 & 3.03 & 1336.0 & 19.1 & 66.3 \\
\hline Variant 4 & 0.145 & 12.2 & 24.6 & 12.7 & 2.69 & 1164.0 & 15.1 & 60.3 \\
\hline Variant 5 & 0.177 & 12.9 & 27.0 & 13.4 & 2.92 & 1216.0 & 16.6 & 56.7 \\
\hline Variant 6 & 0.111 & 14.9 & 32.5 & 14.4 & 3.55 & 1227.0 & 15.5 & 58.7 \\
\hline DL 5\% & 0.050 & 4.78 & 9.0 & 1.6 & 0.6 & 84 & 4.1 & 4.1 \\
\hline DL 1\% & 0.068 & 6.50 & 12.2 & 2.2 & 0.9 & 114 & 5.6 & 5.6 \\
\hline DL .1\% & 0.092 & 8.74 & 16.4 & 3.0 & 1.2 & 154 & 7.6 & 7.6 \\
\hline
\end{tabular}

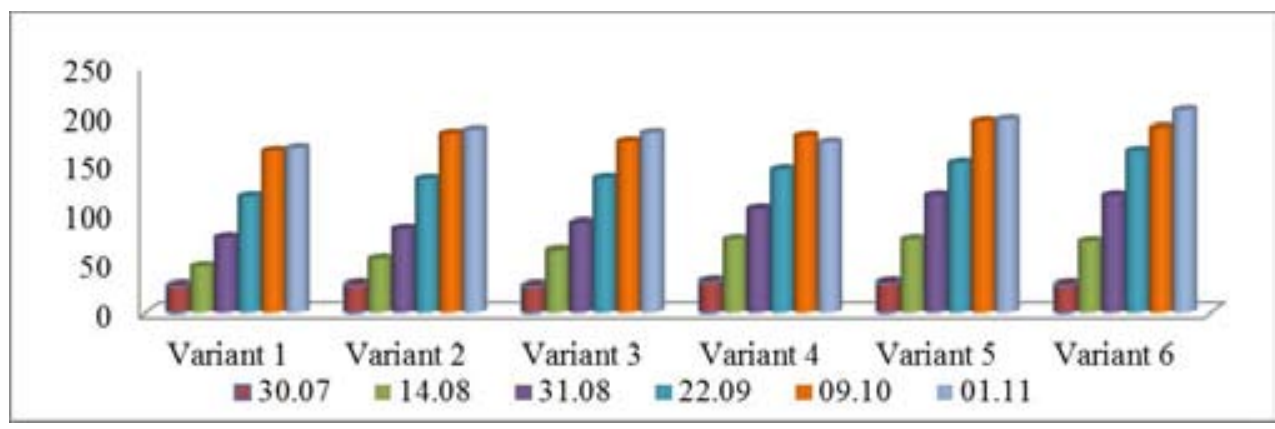

Fig. 1. Albota Albic luvosoil amendment and fertilization effect on the plants waist $(\mathrm{cm})$ during the experimental period

there were determined the content in macronutrients and micronutrients in the maize leaves and grains. The results were presented in Fig. 1-6.

The plant waists were constantly growing in all variants and the amendment and fertilization effects are evident since the early stages, until the final harvesting (Fig. 1). The control variants (V1V3) are far behind in growth against the amended ones, in all the stages without exceptions. The differences between control variants 2 and 3 (amended with organic compost) and variant 4 (amended with organic compost and bauxite residue) are clear proofs of the bauxite residue contribution in all the stages, due to the favorable changes in $\mathrm{pH}$ and improvements in the soil agrochemical properties. The increased share of amendments in soil composition (variant 4 and variant 5) raises proportionally the effect on plants waist growth rate. The growth step up is stronger in the first stages and slowed down in the last stages, when the plant turgor decays. All the data are statistically sustained (Fig. 1).

The amendments and fertilization effect on the weight of maize plant organs is selective and some particularly patterns may be seen for each plant part. The strongest effect is visible on cobs and grains, where yields are almost double than in variants 1-3 (Fig. 2). It seems the mass distribution between the plants organs is not dependent on nutrition level (in the variants 3 and 4 received the same quantities of nutrients with the organic compost), but rather it is dependent on a specified soil $\mathrm{pH}$ threshold. This 
threshold was naturally reached, because the $\mathrm{pH}$ varies from lower value up to the neutral values as a contribution of the bauxite residue adding in soil, which make the difference between the variant 3 and variant 4. Once this threshold has been passed, each part of the plant increases after its own pattern in variants 4, 5 and 6 . In terms of mass growth, every part of the plant has its share. Roots and husks impart the lowest shares. The other plant parts shares are increasing with a rate of about $30 \%$, from the roots to leaves, stems, and to cobs and grains. The highest share belongs to cobs and grains. The increase in all amendment contributions do not change the ratios between plant organs growth shares, but change the size of their shares. Some decreases in plant mass at the highest content of bauxite residue in soil (variant 6) are visible in all the plant organs, excepting the cobs and grains (Fig. 2).

Even if by the planning of experiments, the macro-nutrients supplies were varied from control variants (variants 1-3) to variants 4-6, their effects seems to be discriminatory perceptible at the level of leaves. Nitrogen variation in leaves against the concentration of nitrogen in soil is rather slim, even the ratios of nitrogen/acid soil are increasing from variant 1 to variant 6 . Moreover, the measured concentrations of nitrogen in leaves are far away from the expected minimum normal content. The high demand of nitrogen for rehabilitation of poor and acid soils is well known. The bauxite residue application as an adjuvant could not solve the problem, but it can ease this demand (Fig. 3). Phosphorus level in leaves is closer to the normal content, but its concentration decreases evidently and significantly, as the bauxite residue concentration in soil is increasing from variant 4 (phosphorus content is equal with normal concentration in the maize leaves) to variant 6 . Potassium effect (exceeding in concentration and mobility in soil) is visible, and in the particular instance of variants $4-6$, its concentration is raising up to the normal values for maize. The same conclusion is valid for calcium, due to its exceeding concentrations even in the control samples. Magnesium has a different behavior. It is certitude that the magnesium is collected from soil, because the bauxite residue content is increasing from the variant 4 till the variant 6 (as other authors have noticed [15]). A little jump in the sodium content at the highest concentration of bauxite residue in soil is not unexpected, but this is not a bothering problem (Fig. 3).

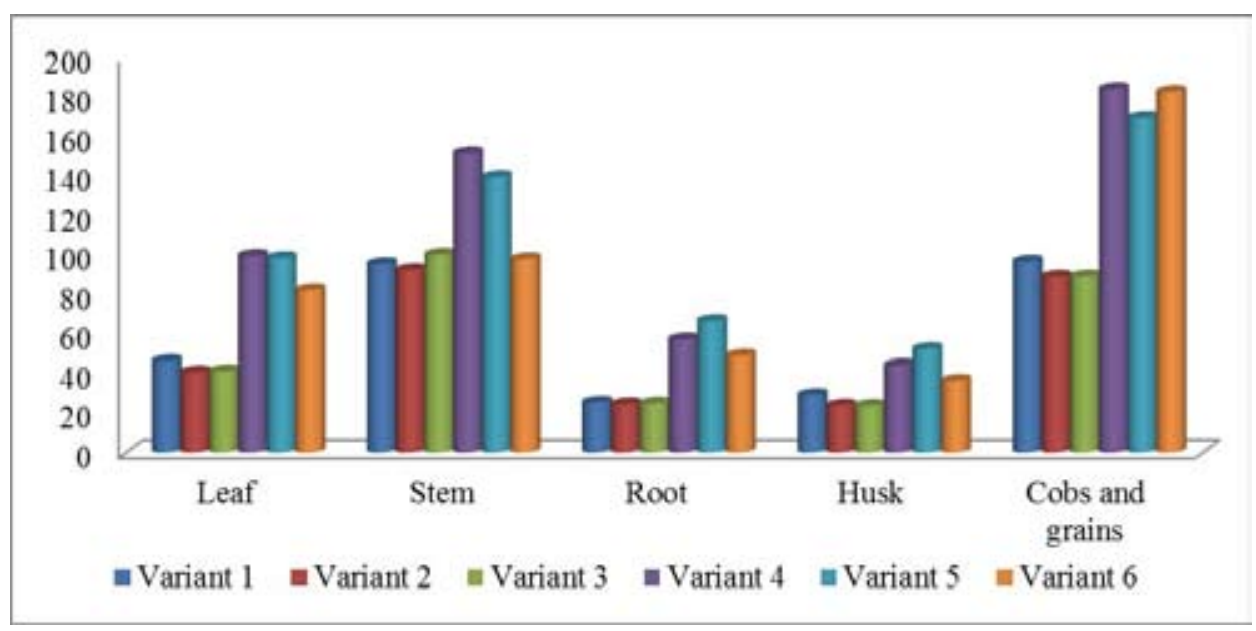

Fig. 2. The Albota albic luvosoil amendment and fertilization effect on the maize mass plant organs (g) after harvesting 
In the Fig. 4 there was presented the data on copper, iron, manganese and zinc in the maize leaves. The measured concentrations are not usual, at least for manganese. The zinc and copper concentrations are normal, but the iron concentration is slightly higher. Most of these micronutrients are coming from the acid soil in any variants.

Roughly, the use of bauxite residue in acid soils rehabilitation programs does not introduce any critical problem concerning the heavy metals. The same conclusion is valid for the content of cadmium and chromium. Actually, the basic dowry in cadmium and chromium in the maize leaves comes from acidic soils (not presented in the Fig. 4).

The macronutrients status in maize grains is quite normal (Fig. 5). The bauxite residue and its increased dosage in variants 4-6 do not change the status of NPK macronutrients. Short nitrogen increases in variants 4-6 is a proof the bauxite residue does not cut off the availability of this element or its accumulation in grains. The same conclusion is valid for potassium. Phosphorus status is a little different. Actually, its availability is affected by the large dosages of bauxite residue, and this explains

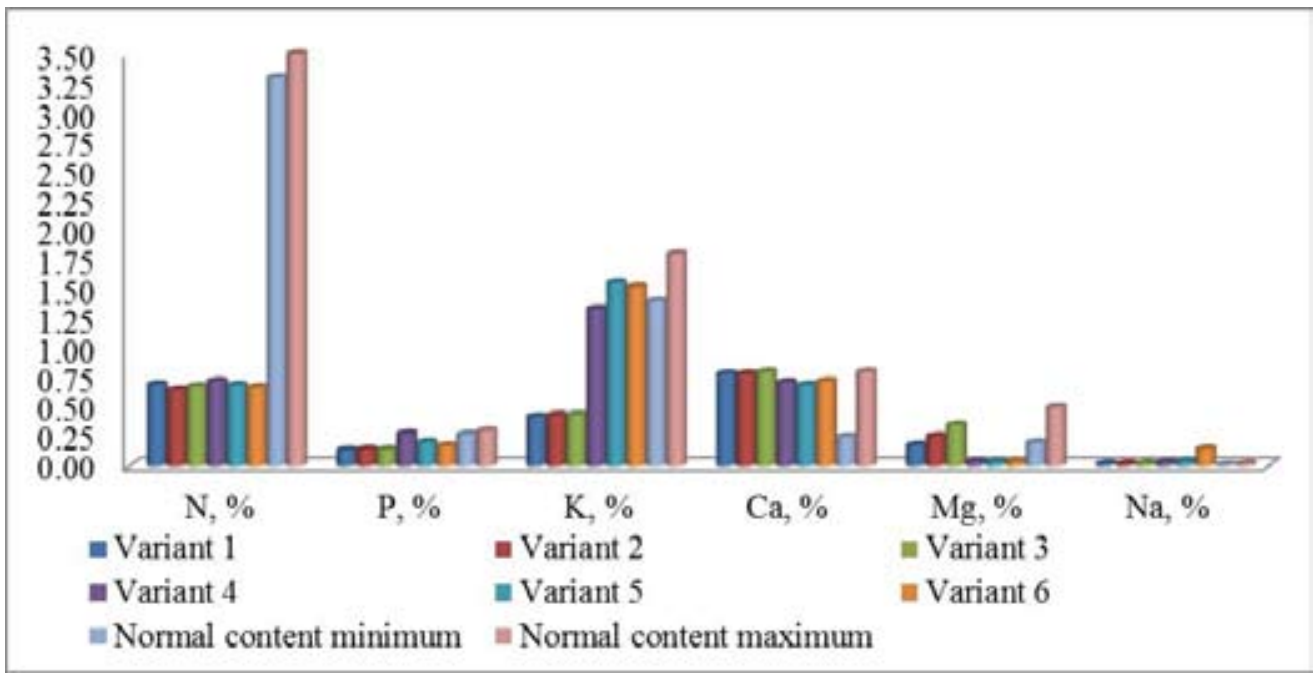

Fig. 3. The Albota Albic luvosoil amendment and fertilization effect on the macronutrients in maize leaves

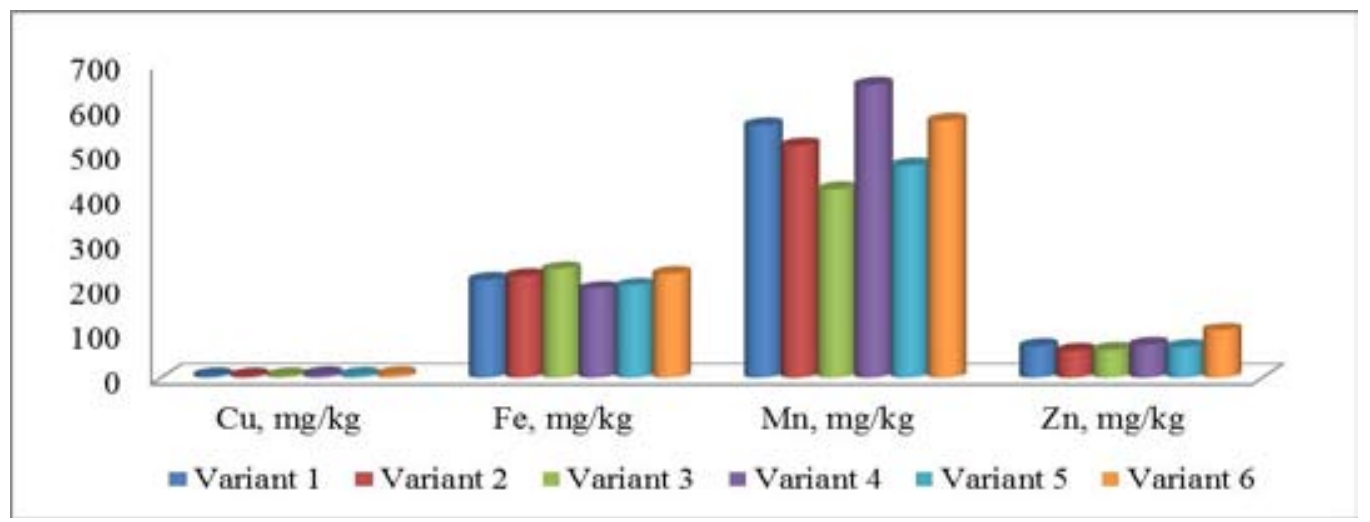

Fig. 4. The Albota albic luvosoil amendment and fertilization effect on the micro-nutrients in maize leaves 


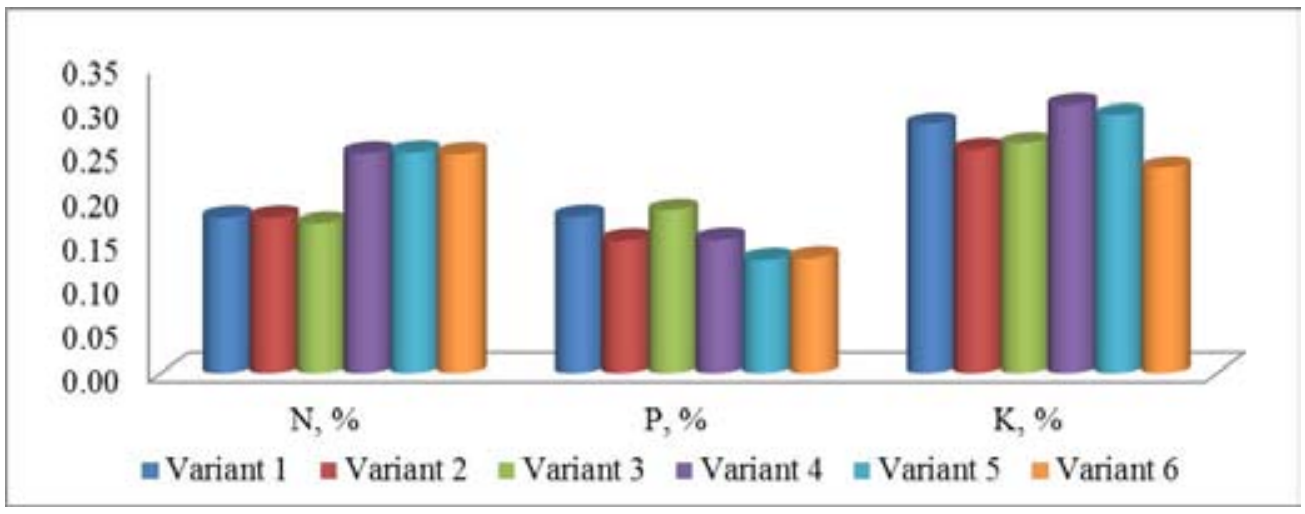

Fig. 5. The Albota Albic luvosoil amendment and fertilization effect on the macronutrients in maize grains

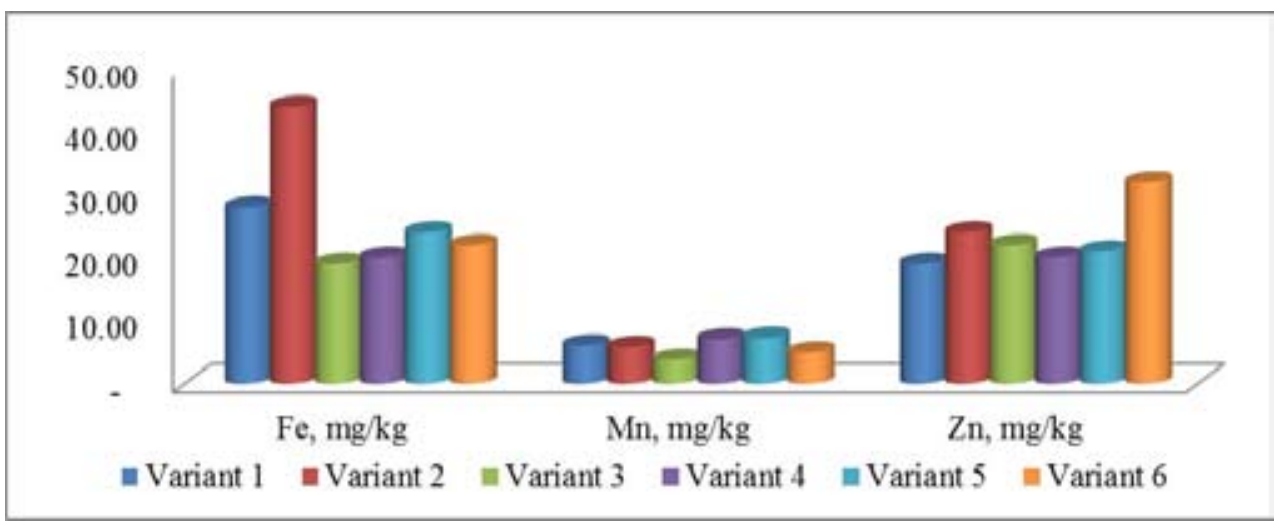

Fig. 6. The Albota Albic luvosoil amendment and fertilization effect on the micro-nutrients in maize grains

its diminishing concentrations in grains. The concentrations of calcium, magnesium and sodium are very low in grains, at least 10-15 times less than those of the main macronutrients (Fig. 5).

The variation of micronutrient concentrations in maize grains is not unusual. Bauxite residue, as adjuvant in the remediation of acid soils, lessens the iron concentration in grains, comparing with control samples (V1-V3). Manganese and zinc concentrations are normal. The other microelement concentrations, like cadmium, cobalt, chromium, copper, nickel and lead, have insignificant values and their variation does not bring in no any meaningful conclusion (Fig. 6).

\section{Conclusions}

A new way for remediation of the Albota luvosoil type acid soils was investigated by reshaping of the soil chemical composition and its agrochemical properties, using the bauxite residue as adjuvant for the $\mathrm{pH}$ control, organic compost as source of organic carbon and adjuvant for the agrochemical properties control and NPK mineral fertilizers as source of main macronutrients; b) By amending of the Albota luvosoil type acid soils with bauxite residue doses of 15, 30 and $75 \mathrm{t} / \mathrm{ha}$, organic compost doses of 40 and $80 \mathrm{t} / \mathrm{ha}$ and mineral fertilizers at doses of $120 \mathrm{Kg} \mathrm{N} / \mathrm{ha}+60 \mathrm{Kg} \mathrm{P}_{2} \mathrm{O}_{5} / \mathrm{ha}+40 \mathrm{Kg} / \mathrm{ha} \mathrm{K} \mathrm{K}_{2} \mathrm{O}$, the surface reshaped layer of acid soil acquired 1.5-2.2 units higher in $\mathrm{pH}$, significant increases in organic 
carbon, total nitrogen, mobile phosphorus and potassium content, and improved agrochemical properties as total ion exchange capacity, total exchangeable bases and medium bases saturation. All without significant increases in soil soluble salt content; c) The above reshaped soil has promoted the intensive vegetative growth in maize plants (waist, green mass and dried mass), as well as high productions in cobs and grains; d) No significant increase in concentration of the macronutrients and micronutrients in maize leaves was noticed, excepting potassium, but without predic Table consequences; e) Even if some significant fluctuations were noticed in the concentrations of heavy metals in leaves, no toxic levels were recorded; f) Some large fluctuations in concentration of the macronutrients, micronutrients and heavy metals in cobs and grain were recorded, but no value exceeded the normal figures; g) By amending of the Albota luvosoil type acid soil only with organic compost leads to some insignificant growths in vegetative mass (Fig. 1) and no growth in maize production indicators, as roots mass per plant, and cob and grains mass per plant (Fig. 2).

\section{References}

1. Dobra G., Filipescu L., Anghelovici N., Alistarh V., Iliev S. Bauxite residue safety disposal and friendly environmental processing permanent care at Vimetco Alum SA Tulcea, Bauxite Residue Valorisation and Best Practices Conference, Leuwen 2015.

2. Courtney R., Harrington T. Growth and nutrition of Holcus lanatus in bauxite residue amended with combinations of spent mushroom compost and gypsum, Land Degradation and Development 2012. Vol. 23(2), p. 144-149.

3. Rai S.B., Wasewar K.L., Mishra R.S., Mahindran P., Chaddha M.J., Mukhopadhyay J., Yoo C.K. Sequestration of carbon dioxide in red mud. Desalination and Water Treatment 2013. Vol. 51(1012), p. 2185-2192.

4. Courtney R., Harrington T., Byrne K.A. Indicators of soil formation in restored bauxite residues. Ecological Engineering 2013. Vol. 58(9), p. 63-68.

5. Courtney R., Mullen G., Harrington T. An Evaluation of Revegetation Success on Bauxite Residue. Restoration Ecology 2009. Vol. 17(3), p. 350-358.

6. Castaldi P., Silvetti M., Santona L., Enzo S., Melis P. X-ray diffraction and thermal analysis of bauxite ore-processing waste (red mud) exchanged with arsenate and phosphate. Clays and Clay Minerals 2011. Vol. 59 (2), p. 189-199.

7. Zhou Y.F., Haynes R.J. Sorption of heavy metals by inorganic and organic components of solid wastes: significance to use of wastes as low-cost adsorbents and immobilizing agents critical. Reviews in Environmental Science and Technology 2010. Vol. 40(11), p. 909-977.

8. Lacatusu R., Stroe V.M., Maruşca T., Rizea N., Lungu M., Stanciu-Burileanu M.M., Lazar R. The effect of acid rock from călimani mountains on making up a nutritive support for plants, based on red mud. Soil Forming Factors and Processes from the Temperate Zone 2013. Vol. 12 (2), p. 1-7.

9. Lacatusu R., Kiselev A., Rizea N., Lungu M., Lazar R., Stanciu-Burileanu M.M., Vranceanu N., Stroe V.M., Popa R.G., Filipescu L. Plant growth suiTable nutritive red mud composite materials from the Romanian dry landfilled red mud. I. Red mud chemical and agrochemical characterization. Rev. Chim (Bucharest) 2014. Vol. 65 (9), p. 1008-1014.

10. Lacatusu R., Kiselev A., Stroe V.M., N. Rizea N., Lungu M., Lazar R., Stanciu-Burileanu M.M., Calciu I., Popa R.G., Filipescu L. Plant growth suiTable nutritive red mud composite materials 
from the Romanian dry landfilled red mud. II. Formulation nutritive composite materials and plant growth tests at laboratory and glasshouse scale. Rev. Chim (Bucharest) 2014. Vol. 65 (11), p. 12941305.

11. Lăcătuşu R., Stroe V.M., Stanciu-Burileanu M.M., Lungu M., Marusca T., Rizea N., Lazar R., Filipescu L. Growth of some pasture plants on a composite nutritive layer with red mud. Research Journal of Agricultural Science 2015. Vol. 47(3), p. 69-78.

12. Dobra G., Kiselev A., Filipescu L., Alistarh V., Anghelovici N., Iliev S. Full analysis of Sierra Leone bauxite and possibilities of bauxite residue filtration. J. Sib. Fed. Univ. Eng. technol. 2016. Vol. 9(5), p. 643-656.

13. Niculescu M., Ionita A.D., Filipescu L. Chromium Adsorption on Neutralized Red Mud. Rev. Chimie (Bucuresti) 2010. Vol. 61(2), p. 200-205.

14. Niculescu M., Ionita A.D., Simion D., Crudu M., Filipescu L. Red mud - new material for tannery residual chromium binding. UPB Sci.Bull. Series Chemistry 2010. Vol. 72 (3), p. 99-114.

15. Mihalache M., Ilie L., Todorova M. Grozeva N. Chemical and physical properties of the Albic luvosoils from Albota-Pitesti. Agricultural Science and Technology 2015. Vol. 7 (3), p. 350-353.

16. Stanila A.L., Dumitru M., Musat M. Contributions to the knowledge of soils from the Pitesti plain for sustainable use. Scientific Papers, USAMV Bucharest, A 2015. Vol. 18, p. 105-112.

17. Sinescu T.V. The influence of nitrogen fertilisation on the triticale culture established on the acid soils from Albota-Arges. Scientific Papers, UASVM Bucharest, A 2010. Vol. 13, p. 195-199.

18. Dana D., Seceleanu I., Raducu D., Anton I., Soare M., Cotet V., Parvan L. Data concerning the characterization of mineral nutrition status of winter wheat plants to ARDS Albota experimental plots. Annals of the University of Craiova-Agriculture, Montanology, Cadastre Series 2009. Vol. 39(1), p. $372-374$.

19. Raducu D, Dana D., Seceleanu I., Craciun C., Anghel A., Gherghina A. Some pedo-ecological characteristics of the active layer of vertic luvosoil from Albota-Arges. Scientific Papers, USAMV Bucharest, A 2009. Vol. 12, p. 43-47.

20. Popescu C., Grecu F., Iancu S., Iancu D., Voicu L. The main physical and chemical characteristics of chernozems in the southern Oltenia. ProEnvironment 2013. Vol. 6, p. 396-401.

21. Iordache M. Abundance of earthworms under fertilization with organo-mineral fertilizers in a chernozem from west of Romania. Journal of Food, Agriculture \& Environment 2012. Vol. 10 (3-4), p. 1103-1105.

22. Lacatusu R. Agrochimie, Ed. II-a. Editura Terra Nostra. Iasi, 2009.

23. Kabat-Pendias A., Pendias H., Trace elements in soils. $3 r d$ Ed. Boca Raton, London. New York 2001.

24. Bergmann W. Nutritional Disorders of Plants. Gustav Fischer Verlag, Jena, Stuttgart, New York, 1992. 